\title{
Role of Fine Needle Aspiration Cytology in the Diagnosis of Male Breast Lesions- A Retrospective Study Over a Five-and-a-Half-Year Period
}

\author{
Phirthangmoi Fimate ${ }^{1}$ \\ ${ }^{1}$ Assistant Professor, Department of Pathology, Jawaharlal Nehru Institute of Medical Sciences (JNIMS), \\ Imphal, Manipur, India.
}

\section{ABSTRACT}

\section{BACKGROUND}

Fine needle aspiration cytology (FNAC) is a simple, reliable, inexpensive, easily acceptable procedure and already has a well-established role in the diagnosis of palpable female breast lesions. However, breast lumps in males are rarely aspirated and hence there is limited cytopathologic experience. The present study aims to determine the role of FNAC in the diagnosis of male breast lesions and also to describe the various cytomorphologic features of these lesions.

\section{METHODS}

The present study is a retrospective analysis of all male breast lesions over a period of five and half years i.e., January 2013 to June 2018 in the Department of Pathology, JNIMS, Manipur. All available data on male breast FNAC done during this period was retrieved from the records of the cytopathology laboratory. The cytologic slides and reports were reviewed and various cytomorphologic features were reassessed. FNAC diagnoses were categorized as benign, malignant, atypical, suspicious and inadequate or unsatisfactory.

\section{RESULTS}

There was a total of 780 patients who underwent breast FNAC during the five- anda-half-year period out of which, 48 were male patients. The most common lesion was gynaecomastia which most commonly occurred in the age group of 51-60 years. Benign breast lesions were found to be more common than malignant breast lesions. Malignant lesions occurred a decade older than benign breast lesions.

\section{CONCLUSIONS}

FNAC is an accurate, safe and simple tool in the diagnosis of male breast lesions. In the hands of an experienced cytopathologist, it is highly sensitive and specific. Therefore, FNAC should be used confidently and be included as a standard first-line investigative procedure in the primary assessment of breast lumps in males as well.

\section{KEY WORDS}

Male Breast Lesions, FNAC, Gynaecomastia
Corresponding Author: Dr. Phirthangmoi Fimate, Ebenezer Villa, Near Shija Hospital, Langol, Imphal West-795004, Manipur, India.

E-mail:drmoite@gmail.com

DOI: $10.14260 / j e m d s / 2019 / 639$

Financial or Other Competing Interests: None.

How to Cite This Article:

Fimate P. Role of fine needle aspiration cytology in the diagnosis of male breast lesions- a retrospective study over a fiveand-a-half-year period. J. Evolution Med. Dent. Sci. 2019;8(39):2939-2943, DOI: 10.14260/jemds/2019/639

Submission 28-07-2019,

Peer Review 11-09-2019,

Acceptance 17-09-2019,

Published 30-09-2019. 


\section{BACKGROUND}

Fine needle aspiration cytology (FNAC) is simple, rapid, safe and cost-effective, and can be performed as a routine office procedure with hardly any complications. In the hands of an experienced cytopathologist, the procedure is both sensitive and specific and has a well-established role in the assessment of palpable female breast lesions, especially in developing countries. However, it is seldom used in males, mostly because male breast lesions are much less frequent. ${ }^{1-8}$

The approach to the diagnostic work-up of breast lesions should be an early diagnosis to relieve the patient's anxiety, save time, and to help in planning proper management. All these can be achieved with the help of FNAC. The success of a breast FNAC procedure depends on the application of welldefined cytologic criteria for assessing adequate tissue sampling and for rendering diagnosis.

In males, gynaecomastia is the most common benign breast lesion,2,4-9 with the most common malignant breast lesion being infiltrating ductal carcinoma, ${ }^{1-10}$ accounting for less than $3 \%$ of all breast carcinomas and less than $1 \%$ of all cancer in males. . $^{1-3,6,10}$

The aim of our study was to determine the role of FNAC in the diagnosis of male breast lesions and also to describe the cytomorphologic features of male breast lesions which were encountered in our hospital setting over a five-and-a-halfyear period.

\section{METHODS}

A retrospective study was conducted over a period of five and a half years, ie., between the period of January 2013 to June 2018. The data of all patients presenting with breast lump who underwent FNAC in the Cytology division of Pathology Department, JNIMS, Manipur, during this period were retrieved and reviewed. Only the male breast cases were further analysed. Details concerning age, clinical presentation, laterality and site of the breast lesions were recorded. Available cytopathologic reports and slides were retrieved and the cytomorphological features of all the lesions were further studied.

Informed consent had been taken. All patients had been made to lie down on the examination bed and all breast lump aspirates had been performed using 22-24-gauge needle and $10 \mathrm{~mL}$ syringe by the cytopathologist under aseptic precautions. The aspirated material was then smeared onto a minimum of 5 clean, dry and grease-free slides. One slide was rapidly stained with Leishman stain for a minute and examined for sample adequacy. Three slides were air dried and stained with May-Grunwald-Giemsa stain. One slide was wet-fixed in 95\% ethyl alcohol and subsequently stained with Papanicolaou stain.

The stained smears were then classified into five major diagnostic categories after screening and interpretation by applying the probabilistic approach ${ }^{11}$ : These were C1 (Non diagnostic or unsatisfactory), C2 (Benign), C3 (Atypical), C4 (Suspicious) and C5 (Malignant).

\section{Criteria}

1. Cellular dyshesion with presence of abundant single epithelial cells or loosely cohesive groups of epithelial cells (this excludes singly bare bipolar cells and stromal cells).

2. Cytologic atypia may be variable but should at least include high nuclear: cytoplasmic ratio and markedly eccentrically located nuclei. Other features which may or may not be present depending on the level of pleomorphism, include nuclear membrane irregularity, coarse and clumped chromatin, multiple and irregular nucleoli.

3. One cell population refers to one population of atypical epithelial cells, as opposed to mixed population of atypical and benign appearing epithelial cells or atypical epithelial cells and stromal cells.

4. Hypercellularity refers to atypical cell population only, rather than increased cellularity due to another component such as inflammatory or stromal cells.

\section{C1, Non-Diagnostic/Unsatisfactory/Unremarkable}

When aspirate is acellular or extremely hypocellular and when it does not yield an explanation of lesion based on information provided by the clinician, it was described as non-diagnostic or unsatisfactory. When none of the four features of carcinoma was present, such lesions were described as unremarkable.

\section{C2, Benign}

When aspirate is cellular with many epithelial cells but with no or mild crowding and overlapping and with obvious myoepithelial cells present.

\section{C3, Atypical}

When aspirate is cellular with many epithelial cells and when epithelial cells present in groups show significant crowding and overlapping and/or aspirate show one other feature of malignancy (Cellular dyshesion, one cell population, cellular atypia)

\section{C4, Suspicious for Malignancy}

When any three of the above four features for malignancy are present

\section{C5, Malignant}

When all four of the above criteria are met

\section{Statistical Analysis}

The Statistical Package for Social Science \{SPSS Version 20 will be used for Data Analysis. Mean, median, and SD are used to describe quantitative data. Qualitative data are summarized using frequency and percentage.

\section{RESULTS}

During the study period of five and half years (5.5 years), seven hundred and eighty (780) patients with palpable breast lumps underwent FNAC at our hospital. Of these, forty-eight (48) cases were males and were included in our study group (Table 1). 
Satisfactory aspirates were obtained in all of the cases. Most of the male patients presented with a painful unilateral breast lump. The right breast was more commonly involved than the left breast. (Table 2). The age at presentation ranged from 13 to 83 years with a mean age of 51.4 years with SD of 18 years and a median age of 53 years. (Table 3 ).

All breast lesions were categorised as benign and malignant. Benign lesions (C2; 46, $95.8 \%$ ) were more common than malignant lesions ( $\mathrm{C} 5 ; 2,4.2 \%$ ). The benign lesions were further categorised as mastitis (breast abscess) and gynaecomastia. (Table 3)

The most common lesion encountered in our study was gynaecomastia $(45,93.7 \%)$. This lesion had the maximum incidence of 12 (25\%) in the age group of 51-60 years of age, with a mean age of 50.7 years (Table 3 ). The right breast was more commonly involved $(29,64 \%)$ as compared to the left breast (Table 3). All patients presented with a tender unilateral lump in the central quadrant. The aspirated smears showed mild to moderate cellularity, composed of tightly cohesive clusters of benign ductal epithelial cell fragments with mild nuclear atypia, some appearing as flat monolayered sheets. Scattered bipolar myoepithelial nuclei were also seen in the background of the smears. (Figure $1 \& 2$ )

We had two cases (4.2\%) of malignant male breast lesions (C5), both presenting in the $7^{\text {th }}$ decade of life (61-70 years), with a mean and median age of 67.5 years, which occurred a decade later than that of gynaecomastia (Table 3). Both patients presented with a single, unilateral painless lump, one of which was in the upper inner quadrant, while the other was in the lower outer quadrant (Table 2). The right breast was as equally involved as the left. On examination, no axillary lymph nodal involvement was found in both the patients. The aspirated smears were hypercellular, composed of malignant cells arranged in loosely cohesive clusters and dispersed singly having intact cytoplasm. The individual tumour cells had moderately pleomorphic vesicular nuclei with irregular nuclear membrane and prominent nucleoli. Occasional tumour giant cells were also noted. No myoepithelial cells were seen. (Figure 3 \& 4)

The remaining one case $(2.1 \%)$ was of breast abscess, presenting with a painful unilateral lump of short duration in the left breast at 50 years of age. On examination, tenderness was present. The aspirated smears showed diffuse sheets of acute inflammatory cell infiltration composed predominantly of neutrophils admixed with scanty lymphocytes and histiocytes along with occasional clusters of benign ductal epithelial cells and scattered benign squamous cells were seen. (Figure 5)

\begin{tabular}{|c|c|c|}
\hline Sex & Frequency & $(\%)$ \\
\hline Male & 48 & 6.15 \\
\hline Female & 732 & 93.85 \\
\hline Total & $\mathbf{7 8 0}$ & $\mathbf{1 0 0}$ \\
\hline \multicolumn{2}{|c|}{ Table 1. Sex Distribution of All Breast Lesions } \\
\hline
\end{tabular}

\begin{tabular}{|c|c|c|c|c|c|c|}
\hline Laterality & Quadrant & Gynaecomastia & Mastitis & Malignant & Total & $\mathbf{( \% )}$ \\
\hline \multirow{2}{*}{ Left } & Central & 16 & 1 & 0 & 17 & 35.4 \\
\cline { 2 - 7 } & Lower outer & 0 & 0 & 1 & 1 & 2.1 \\
\hline \multirow{2}{*}{ Right } & Central & 29 & 0 & 0 & 29 & 60.4 \\
\cline { 2 - 7 } & Upper inner & 0 & 0 & 1 & 1 & 2.1 \\
\hline Total & & $\mathbf{4 5}$ & $\mathbf{1}$ & $\mathbf{2}$ & $\mathbf{4 8}$ & $\mathbf{1 0 0}$ \\
\hline
\end{tabular}

Table 2. Laterality and Site of Different Male Breast Lesions

\begin{tabular}{|c|c|c|c|c|c|c|c|}
\hline \multirow{2}{*}{$\begin{array}{c}\text { Age } \\
\text { (Yr.) }\end{array}$} & \multirow{2}{*}{ C1 } & \multicolumn{2}{|c|}{ Benign Lesions C2 } & C3/ C4 & $\begin{array}{c}\text { Malignant } \\
\text { Lesions C5 }\end{array}$ & Total & \multirow{2}{*}{ (\%) } \\
\cline { 2 - 8 } & & Gynaecomastia & Mastitis & & & & \\
\hline $10-20$ & 0 & 4 & 0 & 0 & 0 & 4 & 8.3 \\
\hline $21-30$ & 0 & 3 & 0 & 0 & 0 & 3 & 6.3 \\
\hline $31-40$ & 0 & 5 & 0 & 0 & 0 & 5 & 10.4 \\
\hline $41-50$ & 0 & 8 & 1 & 0 & 0 & 9 & 18.8 \\
\hline $51-60$ & 0 & 12 & 0 & 0 & 0 & 12 & 25 \\
\hline $61-70$ & 0 & 7 & 0 & 0 & 2 & 9 & 18.8 \\
\hline $71-80$ & 0 & 5 & 0 & 0 & 0 & 5 & 10.4 \\
\hline $81-90$ & 0 & 1 & 0 & 0 & 0 & 1 & 2 \\
\hline Total & $\mathbf{0}$ & $\mathbf{4 5}$ & $\mathbf{1}$ & $\mathbf{0}$ & $\mathbf{2}$ & $\mathbf{4 8}$ & $\mathbf{1 0 0}$ \\
\hline$(\%)$ & 0 & 93.7 & 2.1 & 0 & 4.2 & 100 \\
\hline \multicolumn{7}{|c|}{ Table 3. Age Distribution of Male Breast Lesions } \\
\hline
\end{tabular}

Table 3. Age Distribution of Male Breast Lesions

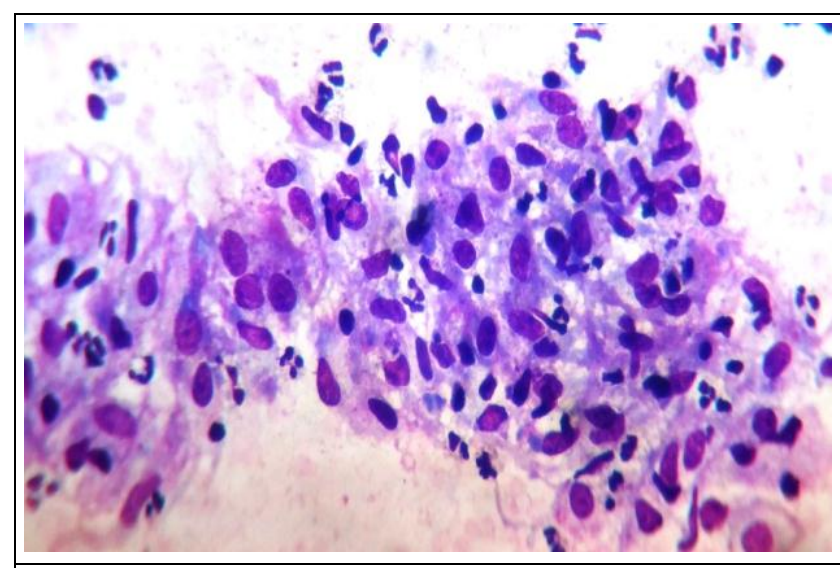

Figure 1. Aspirate Smear of Gynaecomastia Showing Tight Cohesive Clusters of Benign Epithelial Cells with Bipolar Nuclei

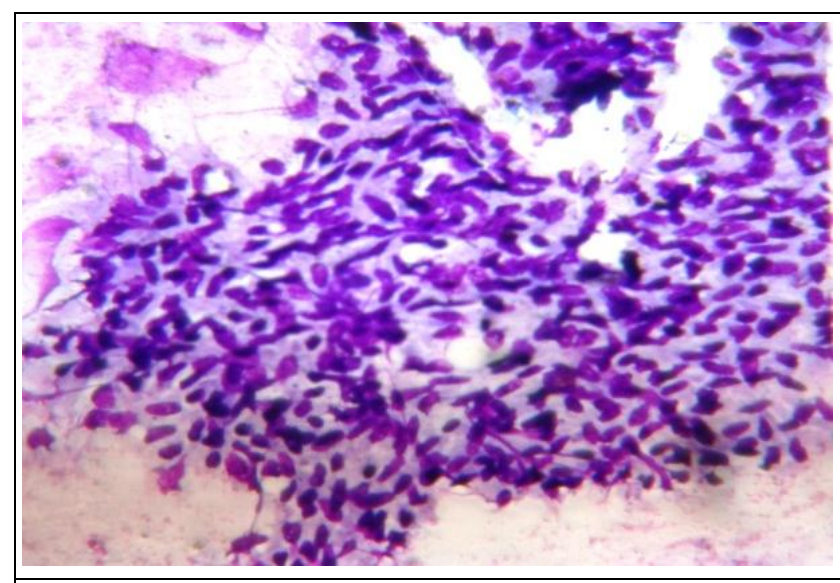

Figure 2. Aspirate Smear of Gynaecomastia Showing Epithelial Cells in Monolayered Sheets

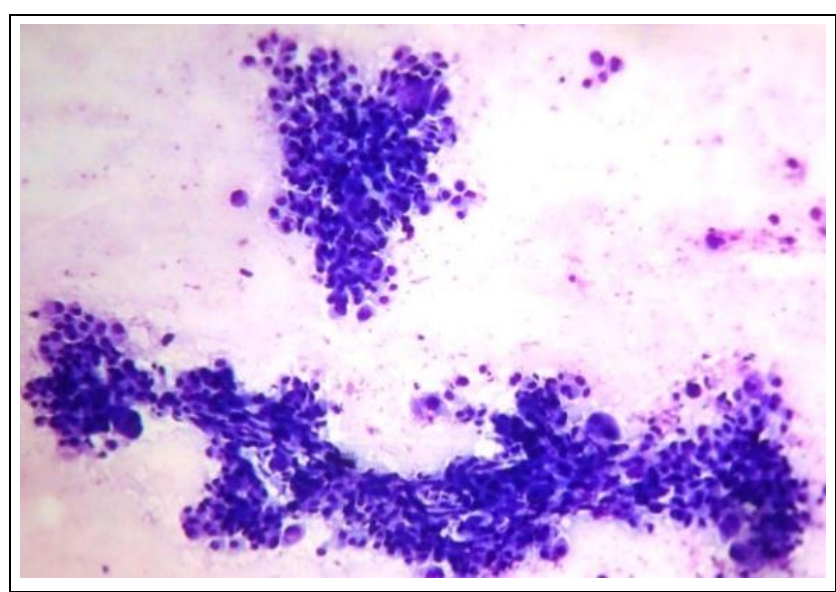

Figure 3. Aspirated Smear of Malignant Breast Lesion, Showing the Hypercellularity at Low Power Magnification 


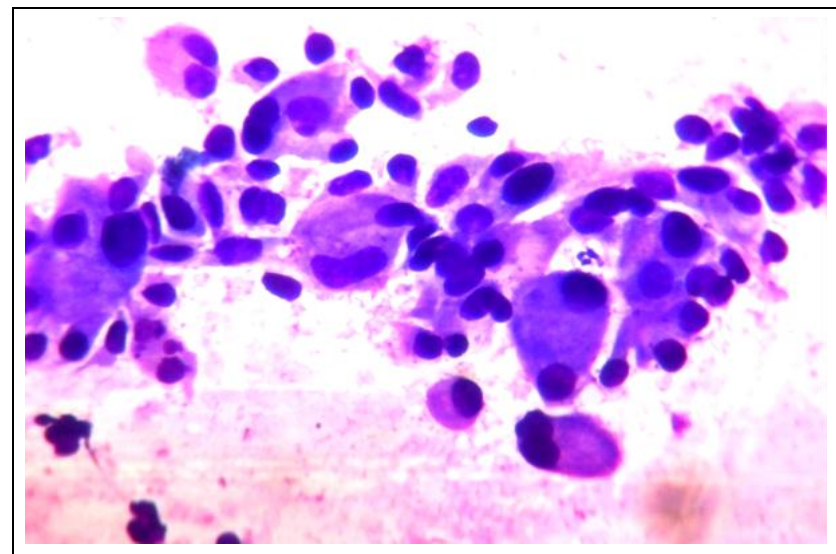

Figure 4. Aspirated Smear of Malignant Breast Lesion Showing Loose Clusters of Pleomorphic Tumour Cells with Multinucleation

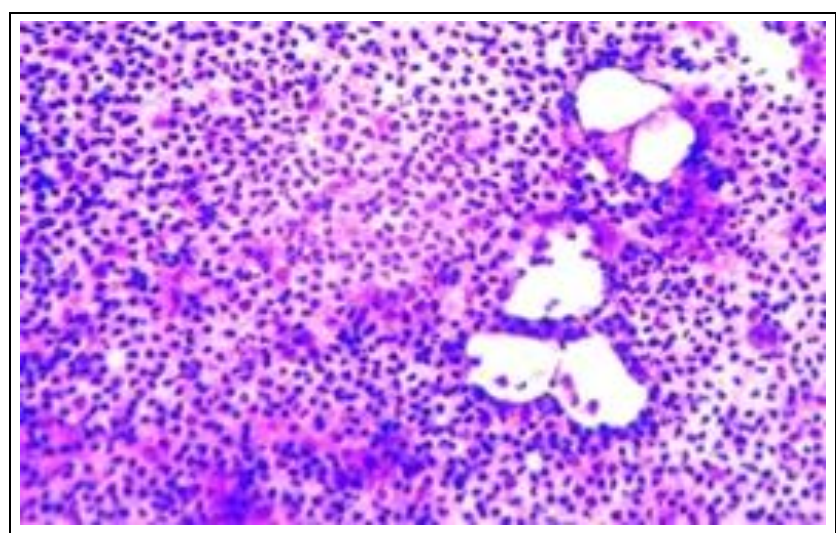

Figure 5. Aspiration Smear of Breast Abscess Showing Dense Neutrophilic Exudates and Few Scattered Squames

\section{DISCUSSION}

FNAC has already a well-established role in the initial evaluation of palpable female breast lesions. It helps to differentiate and further categorise benign and malignant lesions. However, an accurate cytologic report relies on adequacy of the material and experience on the part of the cytopathologist. ${ }^{3}$ A clinico-pathologic correlation was carried out taking into account the sex, age, clinical presentation and symptoms.

\section{Sex Incidence}

According to various studies conducted, breast lesions were reported to be more common in females as compared to males, with male breast lesions accounting to less than $4 \%$ of the total breast cases in various FNAC studies of breast lumps.1,4-6 In the present study, the total number of male breast cases who underwent FNAC was 48 (6.15\%), which was almost similar to a study by Mansoor et $\mathrm{al}^{2}$ where they had an incidence of $6 \%$. In contrast, various studies done by other researchers ${ }^{1,4-6}$ showed a lower incidence of less than $4 \%$ of male breast lesions. (Table 4 )

\begin{tabular}{|c|c|}
\hline & Incidence (\%) \\
\hline Joshi et $\mathrm{al}^{1}$ & 3.9 \\
\hline${\text { Mansoor et } \mathrm{al}^{2}}$ & 6 \\
\hline${\text { Pailoor et } \mathrm{l}^{4}}^{4}$ & 3.6 \\
\hline${\text { Chide et } \mathrm{al}^{5}}^{5} \mathrm{al}^{6}$ & 2.43 \\
\hline Mukhopadhyay et ${ }^{6}$ & 3.95 \\
\hline Present study & 6.15 \\
\hline \multicolumn{2}{|c|}{ Table 4. Incidence of Male Breast Lesions in Various Studies } \\
\hline
\end{tabular}

\section{Age Distribution}

The age range of male breast lesions in our study was 13 to 83 years, similar to many other studies. The mean age at presentation was 51.4 years with SD of 18 years, and a median age of 53 years, which was also similar to studies done by many others too. ${ }^{4-8}$ (Table 5 )

\begin{tabular}{|c|c|c|c|}
\hline & Age Range (Yrs.) & Mean Age (Yrs.) & Median Age (Yrs.) \\
\hline Pailoor et al $^{4}$ & $18-85$ & - & 51.5 \\
\hline Chide et al $^{5}$ & $13-80$ & 43.86 & - \\
\hline${\text { Mukhopadhyay et } \mathrm{al}^{6}}$ & $19-76$ & - & 45 \\
\hline Halder et al $^{7}$ & $07-85$ & 42.39 & - \\
\hline Garima et al $^{8}$ & $11-77$ & - & 44 \\
\hline Kharpade et al & & - & 51.5 \\
\hline Present study & $20-75$ & 51.4 & 53 \\
\hline Table 5. Age Range of Various Studies with Mean or Median Age \\
\hline
\end{tabular}

In males, many studies reported gynaecomastia to be the most common benign breast lesion, presenting in the $4^{\text {th }}-5^{\text {th }}$ decades of life,2,4,8 with a mean age of 31.23 years $^{2}$ and a median age of 45 years. ${ }^{6}$ These reports were in contrast to the present study where gynaecomastia occurred a decade or two later, with a peak incidence of $(12,25 \%)$ at around the $6^{\text {th }}$ decade of life (51-60 years), with a mean age of 50.7 years with SD of 18 years and a median age of 53 years.

Malignant lesions of the male breast were reported at an age range of 22-75 years by Rai et al, ${ }^{10}$ with a mean age 55 years $^{8}$ and a median age of 56.13 years ${ }^{10}$ to 61 years. ${ }^{6}$ In the present study, malignant breast lesions were found in the $7^{\text {th }}$ decade (61-70 years) of life, with a mean and median age of 67.5 years.

\section{Clinical Presentation}

All the cases had unilateral breast lumps, which were similar to the findings by Pailoor et al, ${ }^{4}$ Mukhopadhyay et $\mathrm{al}^{6}$ and Halder et al. ${ }^{7}$

\section{Laterality and Site}

The right breast $(30,62.5 \%)$ was more commonly involved in our study, similar to studies by Garima et al. ${ }^{8}$

\section{Benign Breast Lesions}

Various studies conducted revealed that benign breast lesions in males were more common than malignant breast lesions. ${ }^{1-4,} 6$ Gynaecomastia was reported to be the most common benign breast lesion.1-2, 4-5, 7-9 These reports were similar to our findings in the present study, with benign breast lesions $(46,95.8 \%)$ being more common than malignant breast lesions, and the most common benign breast lesion being gynaecomastia $(45,93.7 \%)$.

All cases of gynaecomastia presented as a single, unilateral lump in the central quadrant of the breast, which was similar to findings by Pailoor et $\mathrm{al}^{4}{ }^{4}$ Mukhopadhyay et $\mathrm{al}^{6}$ and Halder et al. ${ }^{7}$ The right breast $(29,64.4 \%$ ) was more commonly involved as compared to the left breast (Table 3), which is in contrast to findings by Pailoor et $\mathrm{al}^{4}$ and Chide et $\mathrm{al}^{5}$ where the left breast was more commonly involved. There was a peak incidence $(12,25 \%)$ of gynaecomastia cases at around the $6^{\text {th }}$ decade of life (51-60 years), with a mean age of 50.7 years and a median age of 53 years, in contrast to findings Garima et $\mathrm{al}^{8}$ and Pailoor et $\mathrm{al}^{4}$ who reported it in the $4^{\text {th }}-5^{\text {th }}$ decades of life, with a mean and median age of presentation at 31.23 years $^{2}$ and 45 years $^{6}$ respectively. Gynaecomastia of the male breast is regarded as 
a hormone related condition, characterised by the enlargement of the male breast due to proliferation of both glandular and stromal elements. The cytomorphological pattern is not specific, and smears are usually mild to moderately cellular, with large epithelial fragments of benign ductal epithelial cells and many single bare bipolar nuclei. Mild to moderate nuclear variation and atypia can be allowed in the presence of a benign bimodal pattern. ${ }^{3}$ These cytomorphological features were observed in all of the gynaecomastia cases in the present study.

There was one case (2\%) of breast abscess (Mastitis), a 45-year-old male patient presenting with a painful lump on the left breast. On examination, there was a tender lump measuring about $2 \mathrm{~cm}$. Aspirated smears showed diffuse sheets of inflammatory cells composed predominantly of neutrophils admixed with lymphocytes and histiocytes amidst occasional sheets of benign ductal epithelial cells and few scattered squamous cells. These findings were similar to a case report by Silverman et al. ${ }^{12}$

\section{Malignant Breast Lesions}

Carcinoma of the male breast was reported to be very rare as compared to the female breast. ${ }^{1-10}$ There were 2 cases (4.2\%) of male breast carcinomas in our study, almost similar to findings by Mukhopadhyay et $\mathrm{al}^{6}$ (3.9\%). This is in contrast to studies by Pailoor et $\mathrm{al}^{4}$ who found an incidence lower (2.5\%) and Chide et al, ${ }^{5}$ Garima et $\mathrm{al}^{8}$ and Mansoor et $\mathrm{al}^{2}$ where the incidence was higher $(7.4 \%-12.7 \%)$.

Both cases were found in the $7^{\text {th }}$ decade (61-70 years) of life, with a mean and median age of 67.5 years, in contrast to findings by Mukhopadhyay et $\mathrm{al}^{6}$ and Rai et $\mathrm{al}^{10}$ where the mean and median age was 55 years and 56.13- 61 years.

Both patients presented with a single, unilateral painless lump, one of which was in the upper inner quadrant, while the other was in the lower outer quadrant (Table 2). The right breast was as equally involved as the left. On examination, no axillary lymph nodal involvement was found in both the patients.

Aspiration smears of malignant breast lesions are usually cell-rich smears, with a single population of malignant epithelial cells arranged in irregular loosely cohesive clusters and single cells. Individual cells have intact cytoplasm with moderate to severe nuclear atypia characterised by enlargement, pleomorphism, irregular nuclear membrane and chromatin. ${ }^{3}$ These similar findings were also found in both the malignant breast cases (Figure 3 \& 4).

There were no unsatisfactory smears in our study, due to the immediate screening of rapidly stained slides for material adequacy.

\section{CONCLUSIONS}

FNAC is very reliable, safe, easy, cost-effective, and in the hands of an experienced cytopathologist, it is a highly sensitive and specific diagnostic tool for the initial assessment of breast lesions even in male patients. Immediate screening of rapidly stained slides for the presence of adequate material should be encouraged. The routine use of FNAC will greatly reduce the number of unnecessary biopsies and frozen sections for histopathologic evaluation, as now, the trend is shifting towards a less invasive diagnostic procedure. Hence, we strongly recommend the use of FNAC as the first-line investigative choice in the clinical evaluation of male breast lesions.

\section{REFERENCES}

[1] Joshi A, Kapila K, Verma K. Fine needle aspiration cytology in the management of male breast masses. Nineteen years of experience. Acta Cytol 1999;43(3):334-8.

[2] Mansoor I, Jamal A. The value of fine needle aspiration cytology in the diagnosis of male breast lesions. Kuwait Medical J 2001;33(3):216-9.

[3] Orell SR, Sterrett GF, Whitaker D, et al. Breast. Fine needle aspiration cytology. $4^{\text {th }}$ edn. Churchill Livingstone 2005: p. 165-217.

[4] Pailoor K, Fernandes H, Jayaprakash CS, et al. Fine needle aspiration cytology of male breast lesions-a retrospective study over a six year period. J Clin Diagn Res 2014;8(10):FC13-5.

[5] Chide PM, Nayak S, Kumbhalkar D. Role of fine needle aspiration cytology in male breast lesion: 4 year observational study. Int J Res Med Sci 2016;4(9):394550.

[6] Mukhopadhyay P, Rout P. The cytological spectrum of male breast lesions - a peep into the histopathological correlation. Ann Clin Cytol Pathol 2017;3(7):1078.

[7] Halder B, Halder NR. Fine Needle Aspiration Cytology study of male breast lesions: a six year study. J Cytol Histol 2018;9:515.

[8] Garima, Agrawal T. Fine needle aspiration cytology of male breast lesions - a descriptive study over a period of five years. J Evolution Med Dent Sci 2017;6(54):4067-71.

[9] Khaparde SH, Deshmukh SD, Shinde BB, et al. Fine needle aspiration cytological evaluation of male breast lesions. Indian J Appl Res 2018;8(4):24-5.

[10] Rai B, Ghoshal S, Sharma SC. Breast cancer in males: a PGIMER experience. J Can Res Ther 2005;1(1):31-3.

[11] Pandya AN, Shah NP. Breast fine needle aspiration cytology reporting: a study of application of probabilistic approach. Indian Medical Gazette 2013: p. 54-9.

[12] Silverman JF, Raso DS, Elsheikh TM, et al. Fine-needle aspiration cytology of a subareolar abscess of the male breast. Diagn Cytopathol 1998;18(6):441-4. 